\title{
Dişeti çekilmelerinin tedavisinde farklı cerrahi teknikler ile birlikte mine matriks türevlerinin kullanımı: Bir olgu sunumu*
}

\author{
Hacer Şahin Aydınyurt ${ }^{1}$, Eylem Ayhan Alkan ${ }^{1}$
}

Selcuk Dental Journal, 2014; 3: 115-123

Basvuru Tarihi: 9 Mayıs 2014 Yayına Kabul Tarihi: 22 Eylül 2014

\section{Utilization of enamel matrix derivatives with different surgical techniques for the treatment of gingival recessions: A case report}

The combining enamel matrix derivatives (Emdogain) with root coverage procedures has been shown to promote periodontal regeneration on exposed root surfaces. Emdogain induces new periodontal ligament, new bone and new cementum formation. The aim of this case report was to evaluate the clinical efficacy of coronally advanced flap+Emdogain (CPF+EMD), connective tissue graft+Emdogain (CTG+EMD) and connective tissue graft with retained epithelial collar+Emdogain $(E C T G+E M D)$ in the coverage of denuded root surfaces. This case report presents that the surgical periodontal treatment of a 33 year old male patient with Miller class I or II gingival recessions affecting the maxillary and mandibular canines. The left and right upper canines were treated with $\mathrm{CAF}+\mathrm{EMD}$ techniques. On the lower right canine CTG+EMD procedure were used and the lower left canine were treated with $E C T G+E M D$ techniques. The clinical parameters including recession depth, recession width, probing depth, clinical attachment level, keratinized tissue height were recorded and clinical photographs were taken at baseline, 6 months and 3 years after periodontal surgery. Wound healing index was evaluated at post operative 1st and 4th weeks. All preoperative and postoperative clinical assessments were made by a single examiner. All of the operation sites healing was occurred uneventfully. CPF+EMD, CTG +EMD and $E C T G+E M D$ procedures achieved favorable results after 3 years. Increase of keratinize tissue height, clinical attachment level gain and decrease of recessions depth/width were observed. According to the results of the present case report it can be concluded that CPF+EMD, $C T G+E M D$ and $E C T G+E M D$ techniques were highly successful for the coverage of denuded root surfaces.

\section{KEY WORDS}

Connective tissue grafts, coronally positioned flap, enamel matrix derivatives, qinqival recession
Dişeti çekilmelerini tedavi etmek amacıyla saplı greftler, serbest dişeti grefti, bağ dokusu grefti (BDG), epitelli bağ dokusu grefti (EBDG) ve yönlendirilmiş doku rejenerasyonu gibi çok sayıda periodontal cerrahi yöntem geliştirilmiştir (Byun ve ark 2009). Bu teknikler arasında bağ dokusu grefti altın standart olarak düşünülmektedir. Ancak ikinci bir cerrahi alana gerek duyulması bağ dokusu grefti tekniğinin bir dezavantajı olarak düşünülmektedir (Andrade ve ark 2010). Saplı greft tekniklerinden olan koronale pozisyone flep (KPF); hem hasta hem de klinisyen için nispeten kolay bir prosedür olması nedeniyle tercih edilmektedir (Carvalho ve ark 2006).

Dişeti çekilmelerinin tedavisinde kullanılan bir diğer yöntem de mine matriks türevleri (MMT) uygulamalarıdır. MMT domuz diş germinden elde edilmektedir. MMT içeriğinin \% 90'ını amelogeninler oluşturmaktadır (Huang ve ark 2005a). Amelogenin, MMT' nin biyolojik aktivitesinden sorumludur (Chang ve ark 2006). MMT içeriğinin insanlarda doğal mine matriks proteinlerini oluşturan bileşenler ile benzer olduğu

\footnotetext{
* Bu olgu sunumunun 6 aylık sonuçları 2011 yılında 41. Türk Periodontoloji Derneği kongresinde (İstanbul) sunulmuştur.

'Bu makale yazarlarından hiçbirinin makalede bahsi geçen konu veya malzemeyle ilgili herhangi bir ilişkisi, bağlantısı veya parasal çıkar durumu söz konusu değildir

${ }^{1}$ Yüzüncü Yıl Üniversitesi, Diş Hekimliği Fakültesi, Periodontoloji Anabilim Dalı, Van, Türkiye
} 
belirtilmektedir (Sculean ve ark 2003). MMT' nin sement gelişimindeki ana rolünden dolayı periodontal dokuların rejenerasyonunu indüklediği düşünülmektedir. Yapılan birçok klinik çalışma, MMT' nin rejeneratif bir materyal olduğunu desteklemektedir. Histolojik çalışmalarda MMT' nin kök yüzeyine uygulanmasının yeni kemik, yeni periodontal ligament ve yeni hücresiz sement oluşumunu sağladığı gösterilmiştir (Sculean ve ark 2003, Henriques ve ark 2010).

$\mathrm{Bu}$ olgu sunumunda, hastamızın kanin dişlerindeki Miller sınıf I ve II dişeti çekilmelerinin tedavisi için kullanılan KPF+MMT, BDG+MMT ve EBDG+MMT tedavi alternatiflerinin klinik sonuçlarının değerlendirmesi amaçlanmıştır.

\section{OLGU SUNUMU}

Yüzüncü Yıl Üniversitesi Periodontoloji Kliniği'ne dişeti çekilmesi şikayeti ile başvuran 33 yaşındaki erkek hastadan alınan anamnezde, herhangi bir sistemik hastalığının olmadığı ve sigara kullanmadığı öğrenilmiştir. Klinik muayenede, hastamızın üst çene kanin dişlerinde ve sağ alt kanin dişinde Miller sınıf I; sol alt kanin dişinde ise Miller sınıf II dişeti çekilmesi olduğu tespit edilmiştir (Resim 1). Başlangıç periodontal tedavisi yapıldıktan 3 ay sonra hastamız yeniden değerlendirilmiştir. Operasyon öncesi hastadan sözlü ve yazılı onay alınmıştır. Operasyon öncesi kanin dişlerin cep derinliği (CD), klinik ataşman seviyesi (KAS), dişeti çekilme derinliği (DÇD), dişeti çekilme genişliği (DÇG), keratinize doku yüksekliği (KD) ölçülmüştür. İlgili bölgelerde dişeti kalınlığının 1 milimetrenin (mm) altında olduğu tespit edilmiştir.

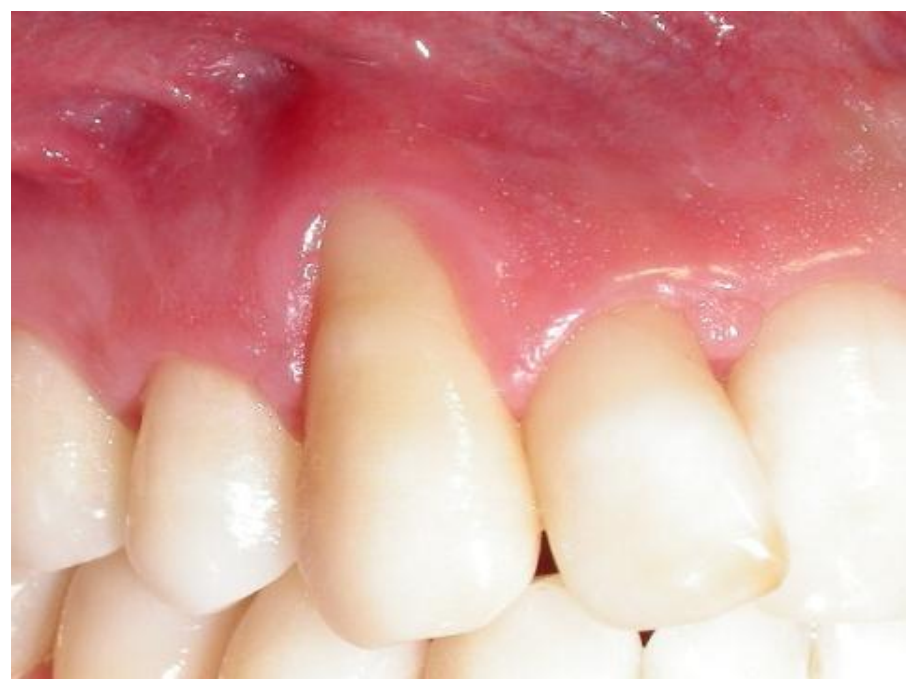

Resim 2a.

13 nolu diş; operasyon öncesi
Dişeti kalınlığı dışındaki ölçümler 6. ayda ve 3. yılda tekrarlanmıştır. Ayrıca erken dönem iyileşmeyi değerlendirmek amacıyla 1 . ve 4 . haftalarda operasyon bölgelerinin yara iyileşme indeksleri kaydedilmiştir. Hastanın üst kanin dişlerindeki Miller sınıf I dişeti çekilmeleri KPF+MMT ile (Resim 2a, 2b, 2c, 2d, 2e, 2f, 2g, 3a, 3b, 3c, 3d, 3e, 3f, 3g), sol alt kanin dişindeki Miller sınıf II dişeti çekilmesi ise EBDG+MMT ile (Resim 4a, 4b, 4c, 4d, 4e, 4f, 4g), sağ alt kanin dişindeki Miller Sınıf I dişeti çekilmesi BDG+ MMT (Resim 5a, 5b, 5c, 5d, 5e, 5f, 5g) ile tedavi edilmiştir.

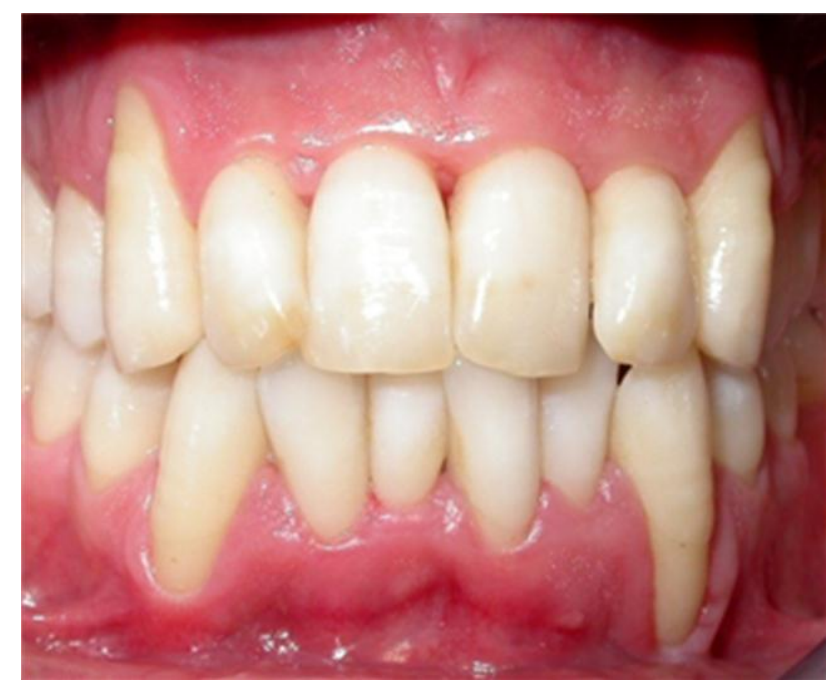

Resim 1.

Operasyon öncesi klinik görüntü



Resim 2b.

13 nolu diş; flebin kaldırılması 


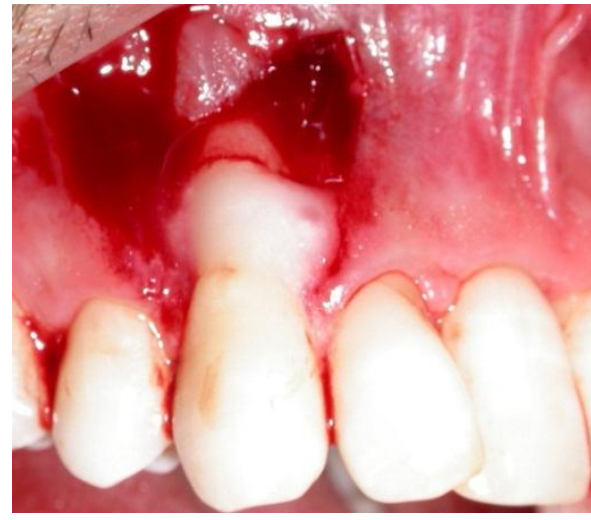

Resim 2c.

13 nolu dişin kök yüzeyine \%24'lük EDTA (Straumann ${ }^{\circledR}$ Prefgel) uygulamas1

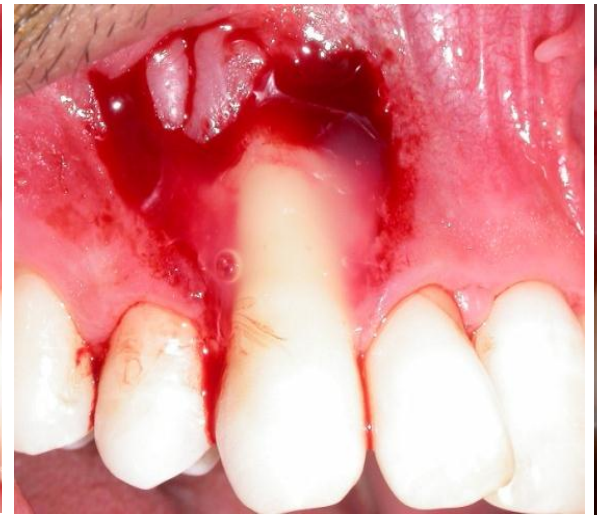

Resim 2d.

13 nolu dişin kök yüzeyine Emdogain uygulaması

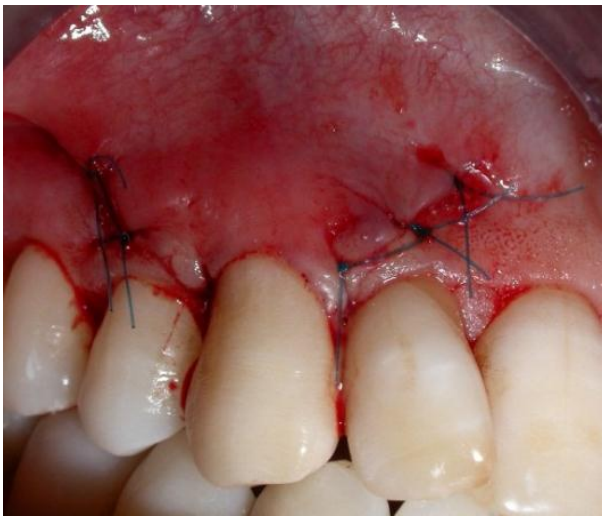

Resim 2e.

Koronale pozisyone flep tekniği ile 13 nolu dişin açık kök yüzeyinin kapatılması

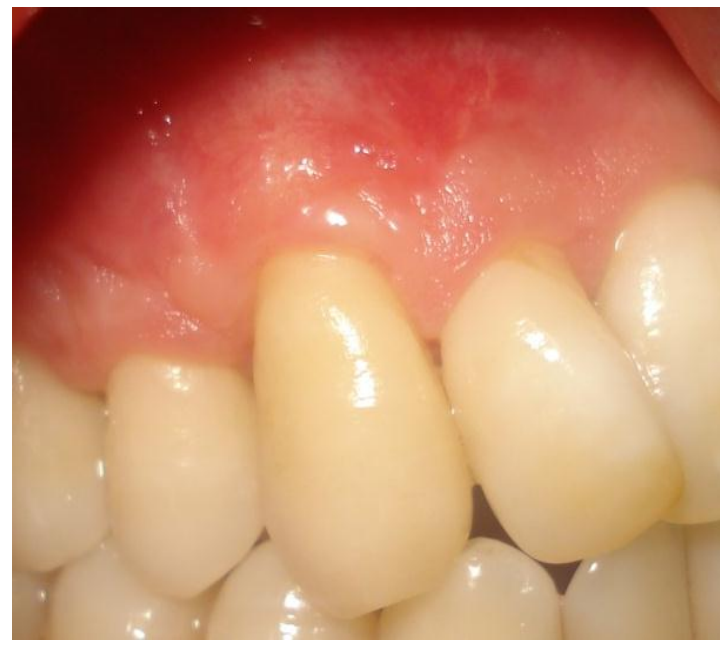

Resim 2f.

13 nolu diş; operasyon sonrası 6.ay

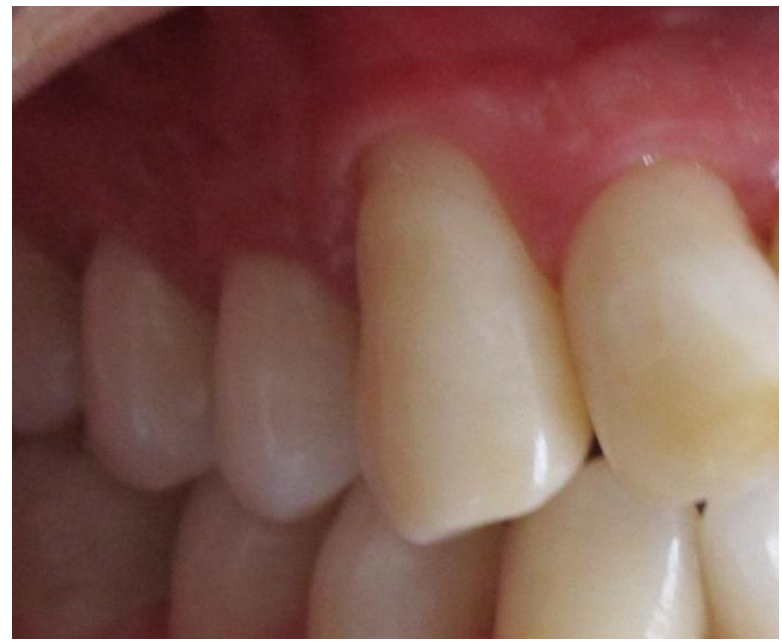

Resim 2g.

13 nolu diş; operasyon sonrası 3. yıl

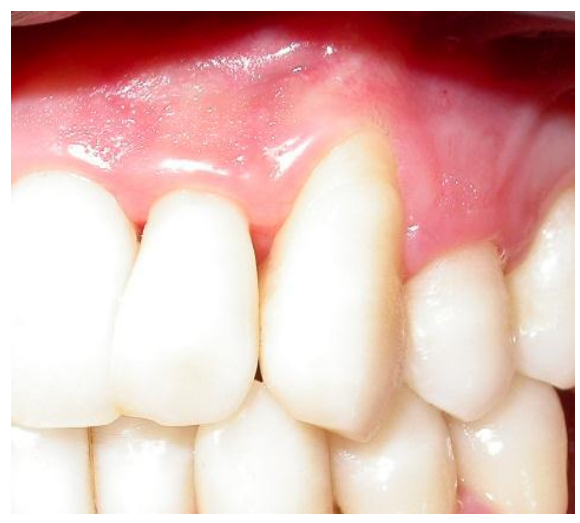

Resim 3a.

23 nolu diş; operasyon öncesi

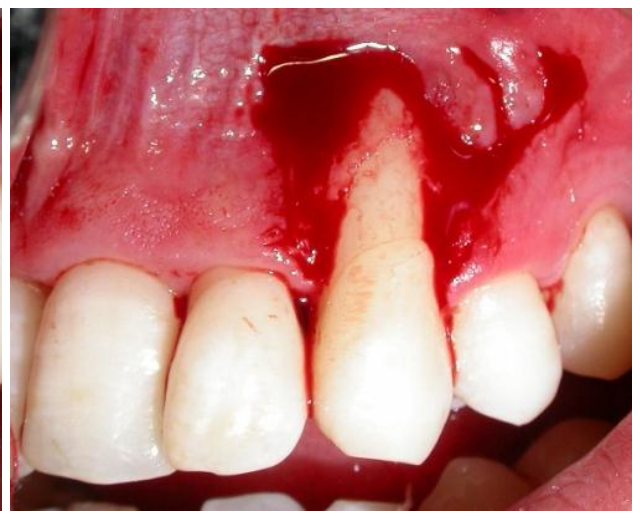

Resim 3b.

23 nolu diş; flebin kaldırılması

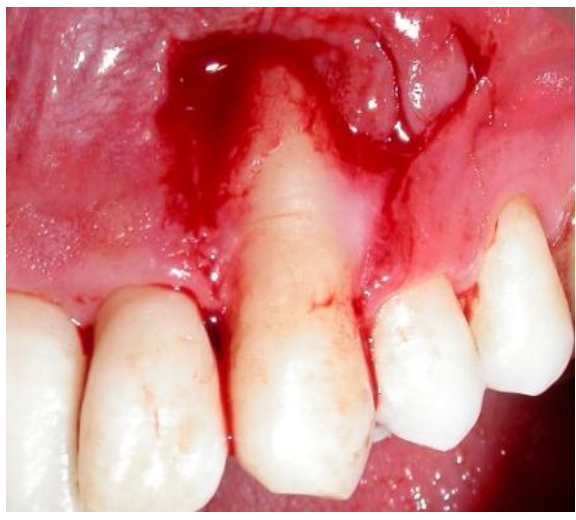

Resim 3c.

23 nolu dişin kök yüzeyine \%24'lük EDTA (Straumann ${ }^{\circledR}$ Prefgel) uygulaması 


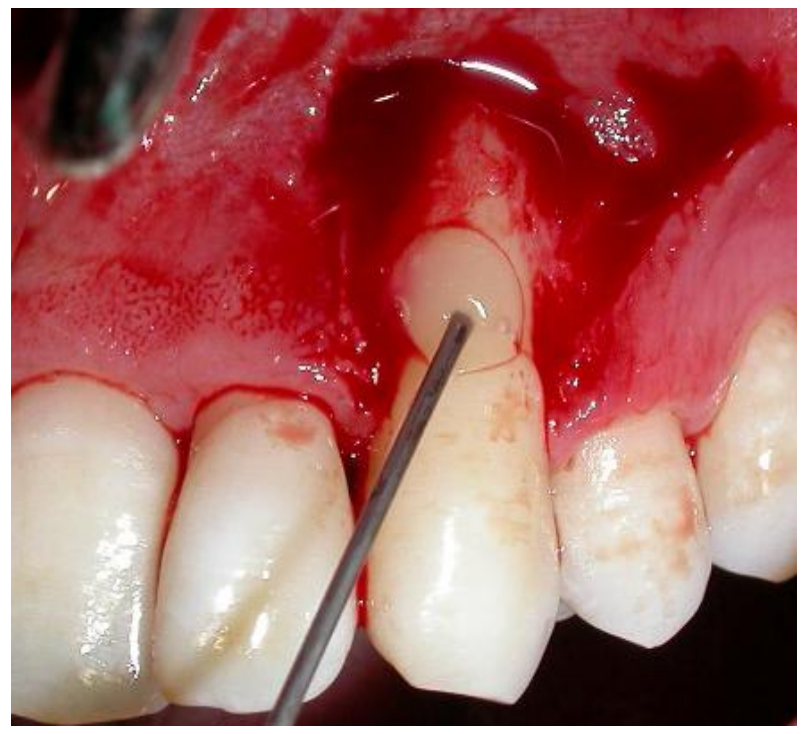

Resim 3d.

23 nolu dişin kök yüzeyine Emdogain uygulaması

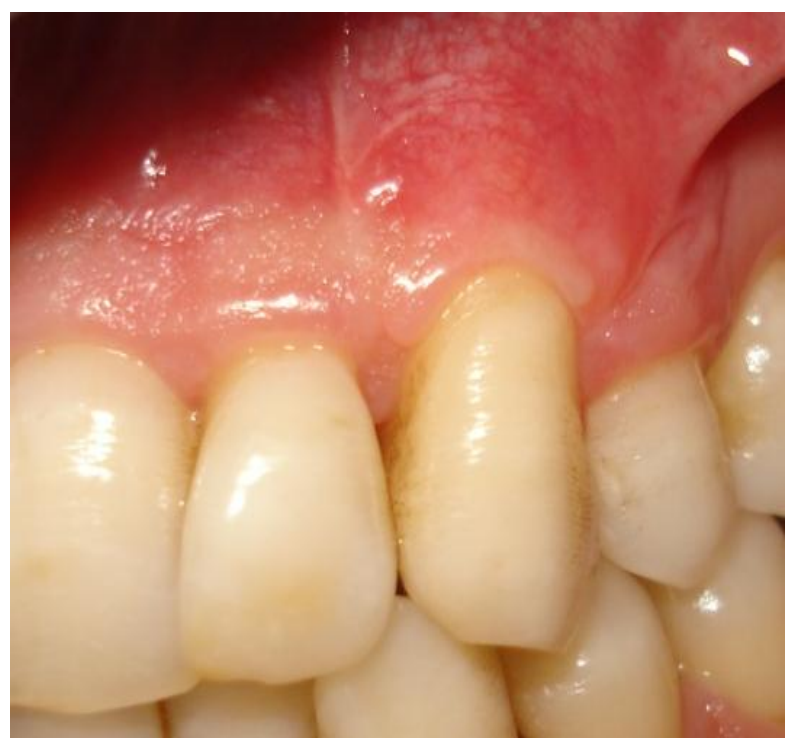

Resim 3f.

23 nolu diş; operasyon sonrası 6.ay

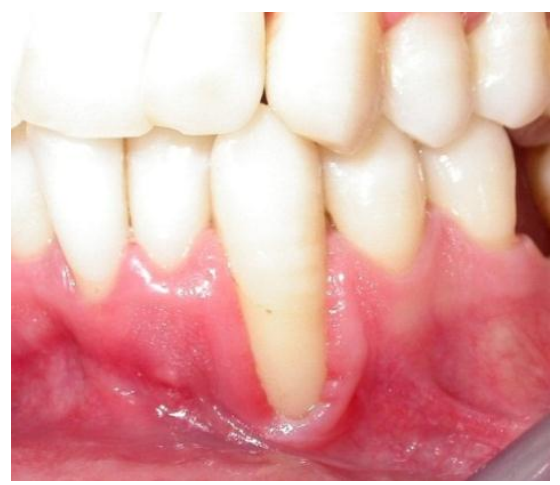

Resim 4a.

33 nolu diş; operasyon öncesi

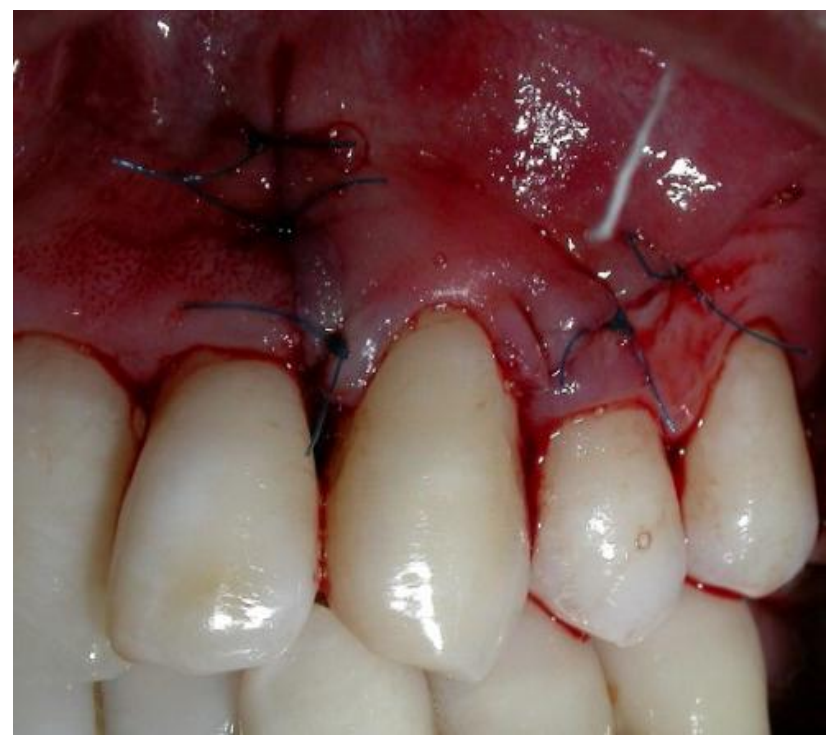

Resim 3e.

Koronale pozisyone flep tekniği ile 23 nolu dişin açık kök yüzeyinin kapatılması

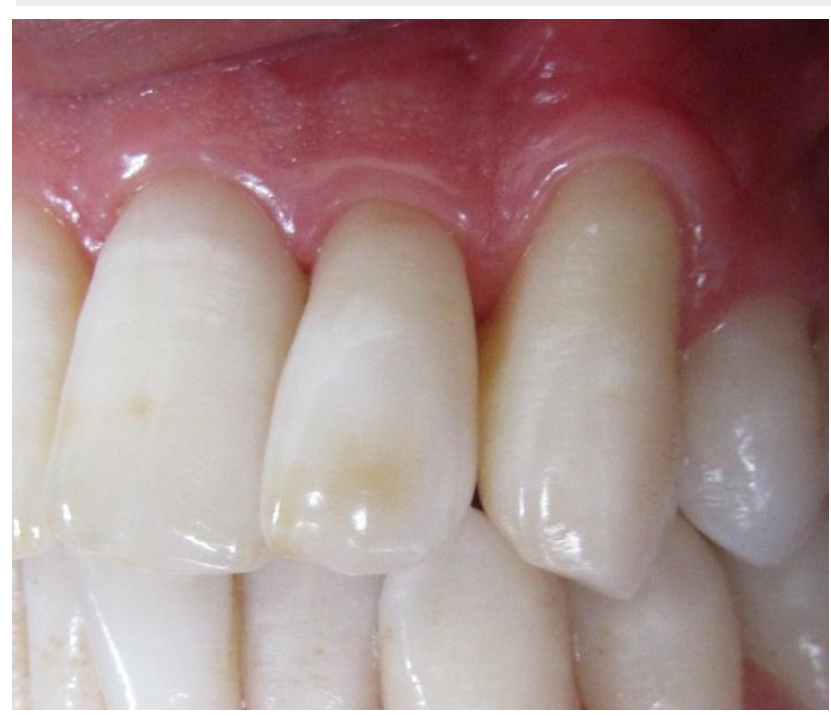

Resim 3g.

23 nolu diş; operasyon sonrası 3.y1l

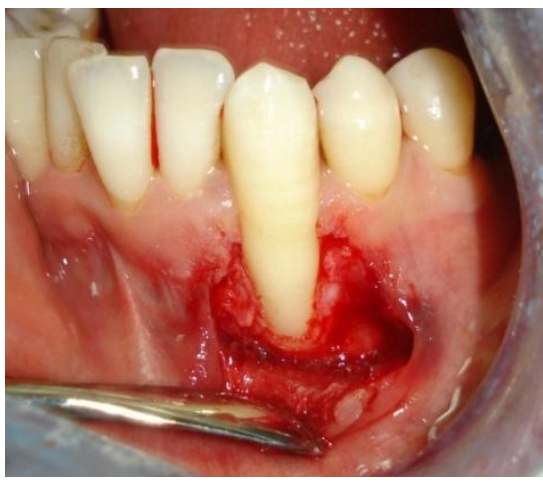

Resim 4b.

33 nolu diş; flebin kaldırılması

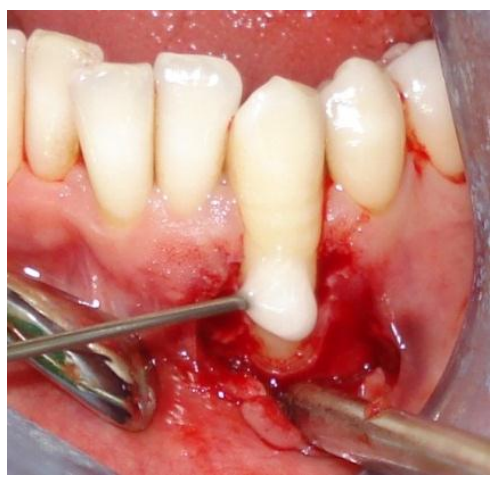

Resim 4c.

33 nolu dişin kök yüzeyine \%24'lük EDTA (Straumann ${ }^{\circledR}$ Prefgel) ve Emdogain uygulamas 


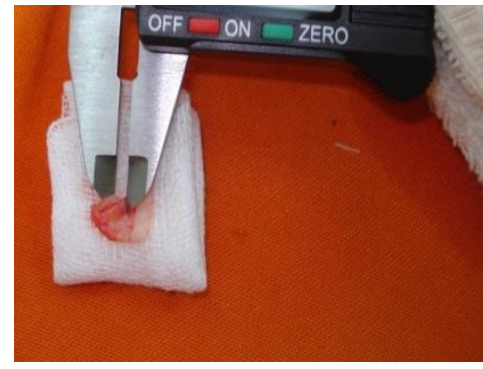

Resim 4d.

Epitel bant içeren subepitelyal bağ dokusu grefti

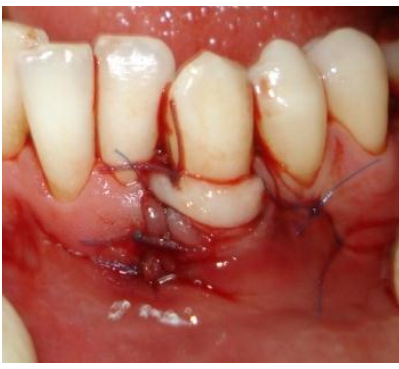

Resim 4e.

Epitel bant içeren bağ dokusu greftinin kök yüzeyine adapte edilmesi ve flebin koronale konumlandırılması

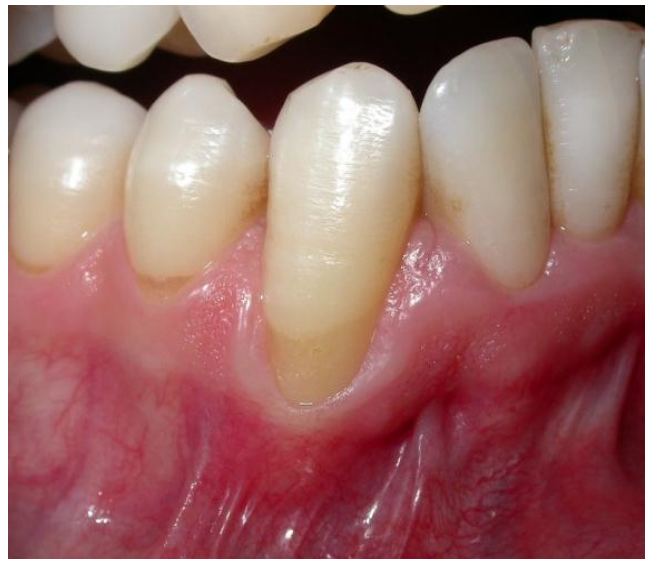

Resim 5a.

43 nolu diş; operasyon öncesi

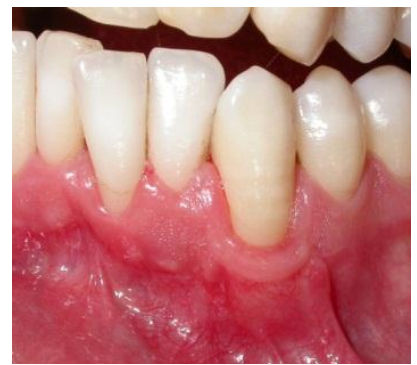

Resim 4f.

33 nolu diş; operasyon sonras 6.ay

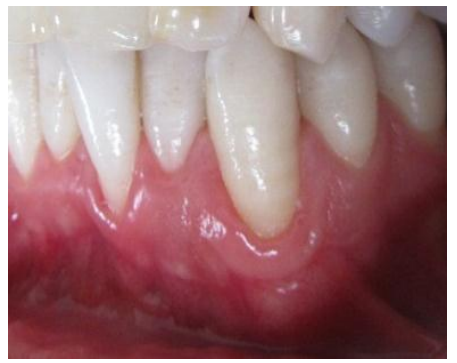

Resim 4g.

33 nolu diş; operasyon sonrası 3.y1l

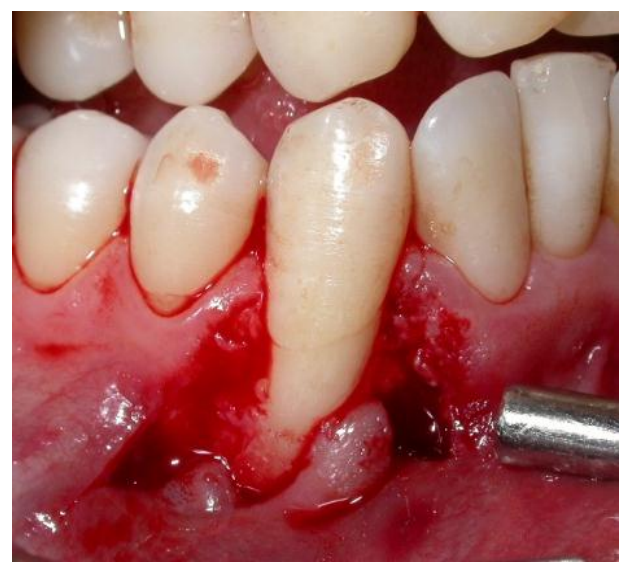

Resim 5b.

43 nolu diş; flebin kaldırılması

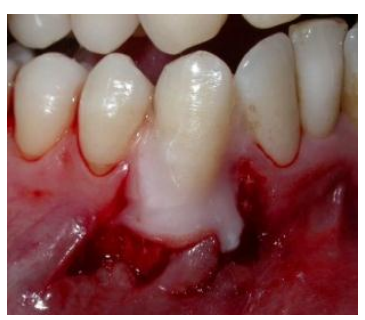

Resim 5c.

43 nolu dişin kök yüzeyine \%24'lük EDTA (Straumann ${ }^{\circledR}$ Prefgel) ve Emdogain uygulaması

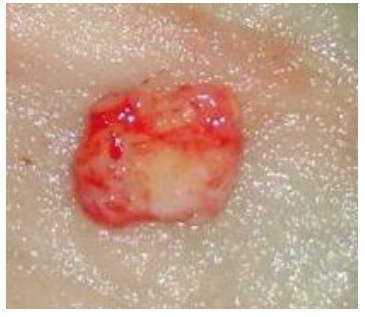

Resim 5d.

Subepitelyal bağ dokusu grefti

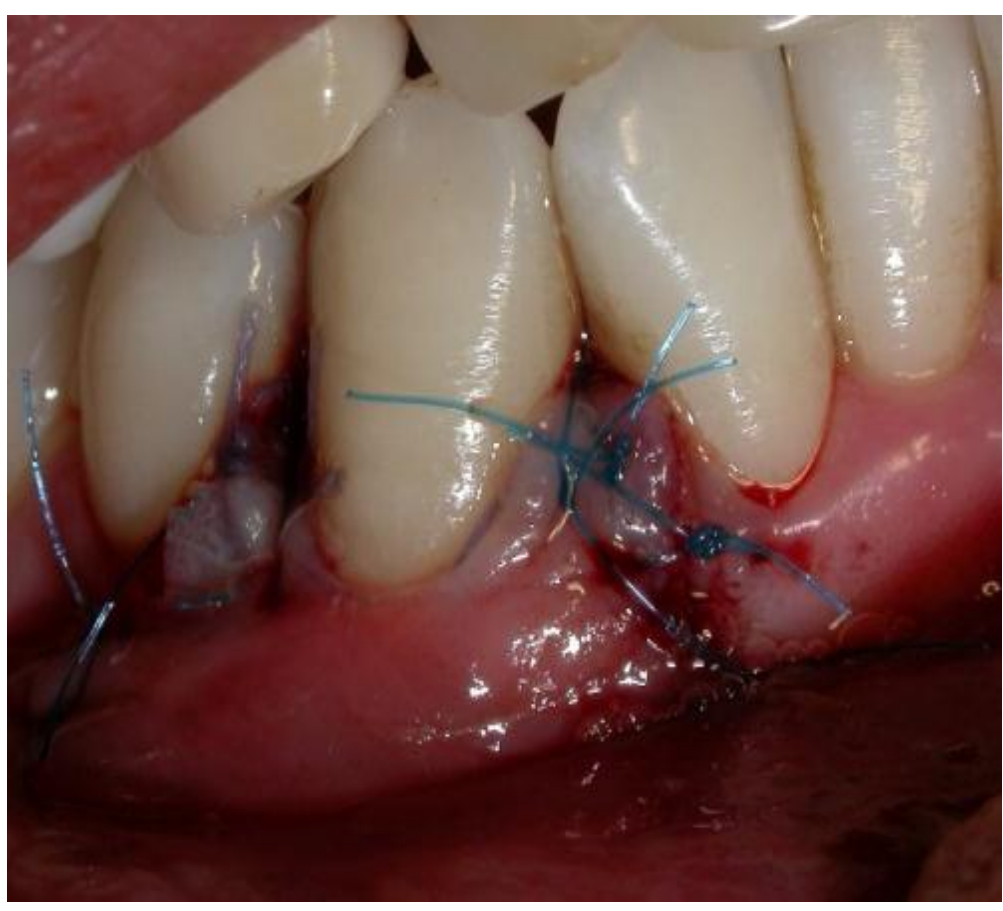

Resim 5e.

Subepitelyal bağ dokusu greftinin kök yüzeyine adapte edilmesi ve flebin koronale konumlandırılması

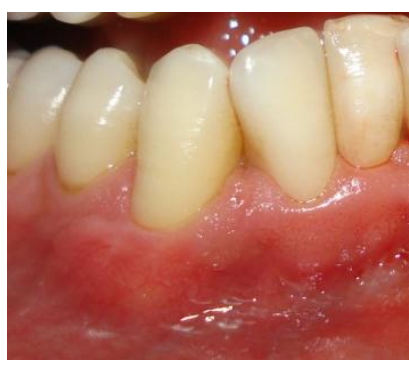

Resim $5 f$.

43 nolu diş; operasyon sonrası 6.ay

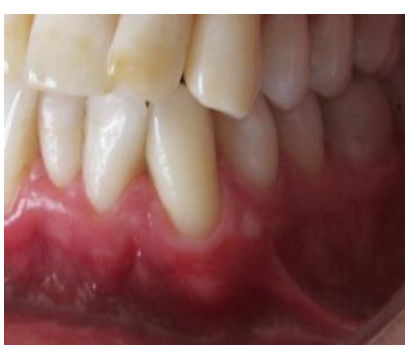

Resim 5g.

43 nolu diş; operasyon sonrası 3.y1l 


\section{KPF+MMT uygulamas1}

Lokal anesteziden sonra üst çene kanin dişler bölgesinde, intrasulkuler insizyon ve intrasulkuler insizyonun mesial ve distal uzantılarından itibaren mukogingingival birleşim hattına doğru, iki adet oblik insizyon gerçekleştirilmiştir. Mukogingival birleşime doğru periost elevatörüyle tam kalınlıklı flep kaldırılmış ardından da flep mobilizasyonunu sağlamak amacıyla periosta horizontal insizyonlar yapılmıştır. Komşu papiller deepitelize edilmiştir.

Kök yüzeyindeki smear tabakasını uzaklaştırmak amacıyla, \%24' lük EDTA (Prefgel, Straumann, Basel, İsviçre) kök yüzeyinde 2 dakika bekletilmiş ve EDTA kalıntılarının operasyon bölgesinden uzaklaştırılması için, serum fizyolojik ile bolca yıkanmıştır. Uygulama öncesi oda sıcaklığında 15 dakika bekletilen MMT (Emdogain, Straumann, Basel, İsviçre) tüm kök yüzeyine uygulanmıştır. Flep koronale pozisyonlandırılarak askı süturla (5.0 propilen) adapte edilmiş ve vertikal insizyonlar basit sütur ile kapatılmıştır. Kalan MMT, son süturdan önce, basit süturların arasından kök yüzeyine enjekte edilmiştir

Bağ dokusu grefti ve epitelli bağ dokusu greftinin elde edilmesi

Alıcı sahanın yukarıda belirtildiği gibi hazırlanmasının ardından sağ alt kanin dişe $B D G+M M T$, sol alt kanin dişe EBDG+MMT uygulanmıştır. Sağ alt kanin diş için, sağ taraf palatinal bölgeden bağ dokusu grefti elde edilirken; sol alt kanin diş için, sol taraf palatinal bölgeden şerit halinde epitel içeren bağ dokusu grefti elde edilmiştir. Greft kalınlığı dijital kumpas ile ölçülmüştür. Greftin üzerindeki yağ dokuları uzaklaştırılmış ve greft uygun kalınlığa getirilmiştir. Prefgel ve MMT uygulamaları yukarıda anlatıldığı gibi gerçekleştirilmiştir. Elde edilen bağ dokusu grefti, kök yüzeyi üzerine askı sütur ile adapte edilmiştir. Flep koronale pozisyonlandırılarak açık kök yüzeyi kapatılmıştır.

Her operasyon sonrası hastaya önerilerde bulunulmuş ve \%12' lik klorheksidin reçete edilmiştir. Yapılan tüm operasyonlardan 10 gün sonra dikişler alınmıştır. Hastanın dört kanin dişinde de operasyon sonrası iyileşme sorunsuz olmuştur. Yara iyileşmesi indeksi (Huang ve ark 2005b) operasyon sonrası 1. haftada üst kanin dişlerde ve sağ alt kanin dişte skor 1 olarak ölçülmüştür. Sol alt kanin dişte yara iyileşmesi indeksi skor 2 olarak kaydedilmiştir. Operasyon sonrası 1. ayda tüm kanin dişlerde yara iyileşmesi indeksi skor 1 olarak ölçülmüştür. Hastamızın operasyon öncesi ve operasyon sonrası 6. ay, 3. yıldaki klinik parametreleri Tablo1'de gösterilmiştir. Operasyon sonrası 6 . ay ve 3 . yılda tüm kanin dişlerde sorunsuz iyileşme gerçekleşmiştir (Resim 6,7).

\section{Tablo 1.}

\section{Periodontal klinik parametreler}

\begin{tabular}{|c|c|c|c|c|c|}
\hline & 13 nolu dis & 23 nolu dis & 33 nolu dis & 43 nolu dis \\
\hline & & (KPF+EMD) & $(\mathrm{KPF}+\mathrm{EMD})$ & $(E B D G+E M D)$ & (BDG +EMD) \\
\hline \multirow{3}{*}{ CD } & 0 & 1 & 1 & 1 & 1 \\
\hline & 6.AY & 1 & 1 & 1 & 1 \\
\hline & 3.YIL & 1 & 1 & 1 & 1 \\
\hline \multirow{3}{*}{ KAS } & 0 & 5 & 4 & 8 & 5 \\
\hline & 6.AY & 2 & 2 & 1 & 1 \\
\hline & 3.YIL & 3 & 2 & 1 & 2 \\
\hline \multirow{3}{*}{ DÇM } & 0 & 4 & 3 & 7 & 4 \\
\hline & 6.AY & 1 & 1 & 0 & 0 \\
\hline & 3.YIL & 2 & 1 & 0 & 1 \\
\hline \multirow{3}{*}{ DÇG } & 0 & 3 & 3 & 4 & 4 \\
\hline & 6.AY & 1 & 2 & 0 & 0 \\
\hline & 3.YIL & 3 & 2 & 0 & 2 \\
\hline \multirow{3}{*}{ KD } & 0 & 4 & 4 & 1 & 5 \\
\hline & 6.AY & 7 & 6 & 7 & 9 \\
\hline & 3.YIL & 6 & 6 & 7 & 9 \\
\hline
\end{tabular}

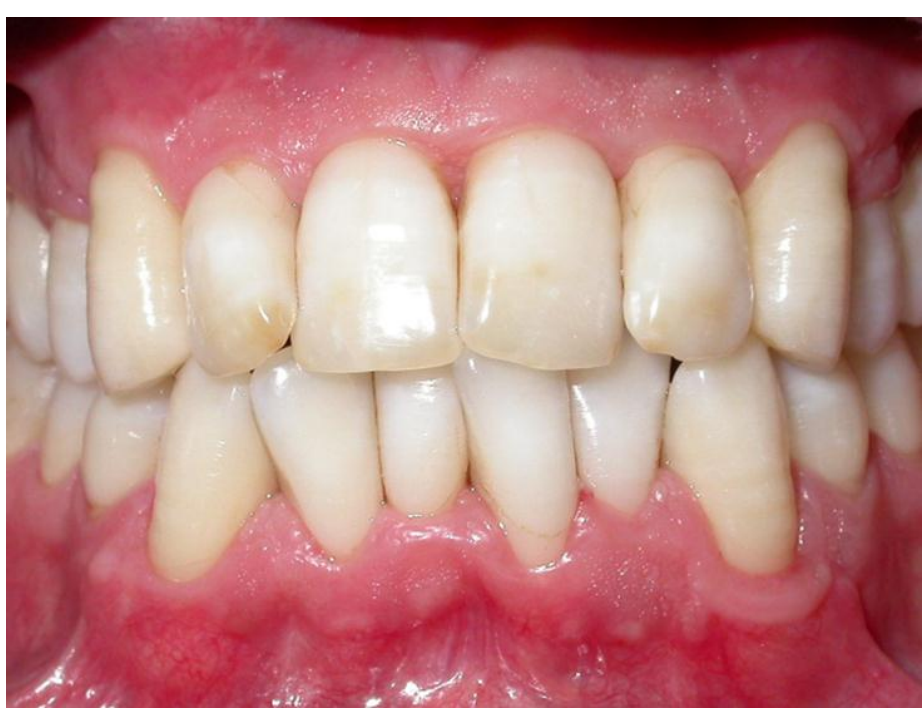

Resim 6.

Operasyon sonrasi 6.ay 


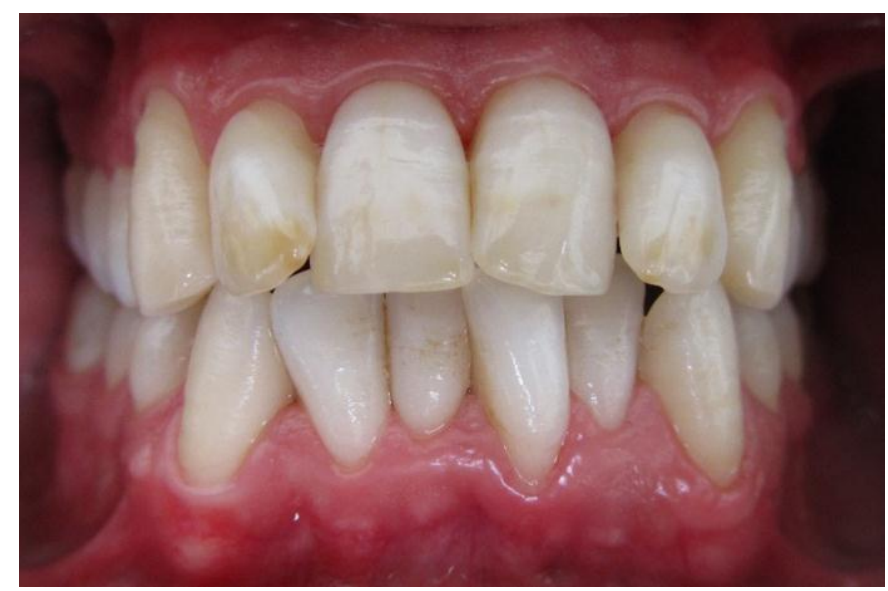

Resim 6.

Operasyon sonrası 3.y11

\section{TARTIŞMA}

Dişeti çekilmelerinin tedavisinde, uzun birleşim epiteli ile sonuçlanan konvansiyonel cerrahi teknikler dışında, çıplak kök yüzeylerinde periodontal rejenerasyonunu sağlamak amacıyla son yıllarda MMT kullanımı gündeme gelmiştir. Hastamızda, tüm kanin dişlerde gerçekleştirilen periodontal cerrahi uygulamalara ek olarak MMT kullanılmıştır.

Moriyama ve ark (2009) KPF'nin, bağ dokusu grefti alınamadığında ve flep koronale yeterince kaydırılabildiğinde kullanılabileceğini; BDG'nin ise flep kök yüzeyini kapatmak için inceyse ve yeteri kadar koronale kaydırılamıyorsa kullanılabileceğini rapor etmişlerdir.

Kök yüzeyi kapatılması işleminin sonuçları doku biyotipi ile yakından ilişkili olduğu bilinmektedir (Huang ve ark 2005a). Başlangıç dişeti kalınlığı, kök yüzeyinin tamamen kapatılmasında en önemli faktör olarak görülmektedir. Claffey ve Shanley (1986), kalınlığı 1,5 mm'nin altında olan dişetini ince biyotipte dişeti, kalınlığı $2 \mathrm{~mm}$ ve üzerinde olan dişetini ise kalın biyotipte dişeti olarak tarif etmiştir. Aynı otörler kök yüzeyi kapatılması işleminde dişeti kalınlığının en az 0,8- 1,2 mm olmasının işlemin başarısını arttıran bir faktör olduğunu belirtmiştir. $\mathrm{Bu}$ vakada $\mathrm{KPF}+\mathrm{MMT}$ tekniği uygulanan üst kanin dişlerde operasyon sonrası görülen $1 \mathrm{~mm}$ 'lik dişeti çekilmesinin, bu bölgede dişetinin ince biyotipte olması ile ilişkili olduğu düşünülmektedir.

Bilindiği üzere, bağ dokusu greftinin başarısı greftin canlıı̆̆ını koruyabilmesine bağlıdır. Greftin beslenmesi başlangıçta diffüzyon şeklinde olmaktadır. Diffüze olan sıvı, greftin beslenmesini ve hidrasyonunu sağlamaktadır. Operasyon bölgesinde erken dönem yara iyileşmesini hızlandırmak ve anjiyogenezi stimule etmek amacıyla MMT kullanımı tercih edilmektedir (Kauvar ve ark 2010). Sol alt kanin dişte, greft üzerinde bırakılan epitelin, epitel ile greft arasında daha yumuşak bir geçiş sağlayacağı düşünülmüştür (Byun ve ark 2009). Prognozun daha iyi olacağı düşüncesiyle Langer ve Langer (1985) tarafından tanımlanan flep tekniği kullanılmıştır. Şerit halinde palatinal keratinize doku içeren EBDG alıcı yatağa yerleştirilmiştir. Rosetti ve ark (2013) 12 hasta üzerinde yaptıkları çalışmada dişeti çekilmelerinde, BDG ve yönlendirilmiş doku rejenerasyonu yöntemlerinin her ikisinde de uzun dönemde başarılı sonuçlar elde edildiğinin ancak BDG'nin keratinize doku yüksekliğinin artırılmasında daha etkin olduğunu rapor etmiştir. Dişeti çekilmelerinin tedavisinde MMT kullanımı ile ilgili başarılı sonuçların elde edildiği pek çok çalışmada gösterilmiştir (Andrade ve ark 2010, Henriques ve ark 2010, Moriyama ve ark 2009, Sayar ve ark 2013, Alkan ve Parlar 2013). Bu vaka raporundan elde edilen sonuçlar da bu çalışmalar ile uyumlu bulunmuştur. Ancak bu olgu raporunun sonuçları ile farklı cerrahi tekniklerde mine matriks türevlerinin ilave etkisinin olabileceğini söylemek mümkün değildir.

\section{SONUÇ}

$\mathrm{Bu}$ olgudan elde edilen sonuçlar KPF+MMT, $B D G+M M T$ ve EBDG+MMT periodontal cerrahi tekniklerinin, kök yüzeyi kapatılmasında başarılı teknikler olduğunu desteklemektedir. Yöntemler arasındaki farklılığın belirlenmesi ve MMT'nin farklı cerrahi teknikler üzerinde etkisinin tam olarak anlaşılması için daha fazla çalışmaya gerek duyulmaktadır. 


\section{Dişeti çekilmelerinin tedavisinde farklı cerrahi teknikler ile birlikte mine matriks türevlerinin kullanımı: Bir olgu sunumu}

Dişeti çekilmelerinin tedavisinde, uzun birleşim epiteli ile sonuçlanan konvansiyonel cerrahi teknikler dışında, çıplak kök yüzeylerinde periodontal rejenerasyonu sağlamak amacıyla son yıllarda mine matriks türevleri (MMT) kullanımı gündeme gelmiştir. Yapılan çalışmalarda MMT'nin yeni periodontal ligament, kemik, sement oluşumunu uyardığı gösterilmiştir. $\mathrm{Bu}$ olgu raporunun amacı: kök yüzeyi kapatılmasında, koronale pozisyone flep (KPF) ile birlikte MMT, epitel bant içeren subepitelyal bağ dokusu grefti (EBDG) ve epitel bant içermeyen supepitelyal bağ dokusu grefti (BDG) ile birlikte MMT uygulamalarının etkinliğinin klinik olarak değerlendirilmesidir. Yüzüncü Yıl Üniversitesi Diş Hekimliği Fakültesi'ne dişeti çekilmesi şikayeti ile başvuran 33 yaşında, sistemik olarak sağlıklı erkek hastaya ait alt, üst çene kanin dişlerde bulunan dişeti çekilmeleri periodontal plastik cerrahi yöntemler ile tedavi edilmiştir. Başlangıç periodontal tedaviyi takiben hasta yeniden değerlendirilmiş ve cerrahi operasyonlar gerçekleştirilmiştir. 13, 23 nolu dişlerde bulunan Miller sınıf 1 dişeti çekilmeleri, KPF+MMT ile tedavi edilirken, 43 nolu dişteki Miller sınıf I dişeti çekilmesi BDG+MMT ile, 33 nolu dişte bulunan Miller sınıf II dişeti çekilmesi EBDG+MMT ile tedavi edilmiştir. Klinik parametreler; sondalama derinliği, klinik ataşman seviyesi, keratinize doku yüksekliği, çekilme derinliği, çekilme genişliği, yapışık dişeti genişliği operasyon öncesinde, operasyon sonrası 6. ayda ve operasyon sonrası 3. yilda değerlendirilmiştir. Operasyon sahasının yara iyileşme indeksi cerrahi sonrası 1 . ve 4 . haftada kaydedilmiştir. Kullanılan üç teknikte de yapışık dişeti genişliğinde ve keratinize doku yüksekliğinde artış, dişeti çekilme genişliği ve derinliğinde azalma, sondalama derinliğinde azalma, klinik ataşman seviyesinde kazanç görülmüştür. Bu olgu raporundan elde edilen klinik veriler $\mathrm{KPF}+\mathrm{MMT}$, $\mathrm{EBDG}+\mathrm{MMT}, \mathrm{BDG}+\mathrm{MMT}$ tekniklerinin açık kök yüzeyinin kapatılmasında başarılı olduklarını göstermektedir.

\section{ANAHTAR KELIMELER}

Bağ dokusu grefti, dişeti çekilmesi, koronale pozisyone flep, mine matriks türevleri

\section{KAYNAKLAR}

Alkan EA, Parlar A, 2013. Enamel matrix derivative (emdogain) or subepithelial connective tissue graft for the treatment of adjacent multiple gingival recessions: a pilot study. Int $\mathrm{J}$ Periodontics Restorative Dent, 33, 619-625.

Andrade PF, Grisi MFM, Marcaccini AM, Fernandes PG, Reino DM, Souza SLS, Taba M, Palioto DM, Novaes AB, 2010. Comparison between micro- and macrosurgical techniques for the treatment of localized gingival recessions using coronally positioned flaps and enamel matrix derivative. J Periodontol, 81, 1572-1579.

Byun $\mathrm{H}$, Oh T, Abuhussein H, Yamashita J, Soehren SE, Wang $H, 2009$. Significance of the epithelial collar on the subepithelial connective tissue graft. $J$ Periodontol, 80, 924-932.

Carvalho PFM, da Silva RC, Cury PR, Joly JC, 2006. Modified coronally advanced flap associated with a subepithelial connective tissue graft for the treatment of adjacent multiple gingival recessions. $\mathrm{J}$ Periodontol, 77, 1901-1906.

Chong $\mathrm{CH}$, Carnes DL, Moritz AJ, Oates T, Ryu OH, Simmer J, Cochran DL, 2006. Human periodontal fibroblast response to enamel matrix derivative, amelogenin, and platelet-derived growth factor-BB. J Periodontol, 77, 1242-1252.

Claffey N, Shanley D, 1986. Relation ship of gingival thickness and bleeding to loss of probing attachment in shallow sites folllowing nonsurgical periodontal theraphy. J Clin Periodontol, 13, 654657.

Henriques PS, Pelegrine AA, Nogueira AA, Borghi $M M, 2010$. Application of subepithelial connective tissue graft with or without enamel matrix derivative for root coverage: a split-mouth randomized study. J Oral Sci, 52, 463-471.

Huang LH, Neiva RE, Wang HL, 2005a. Factors affecting the outcomes of coronally advanced flap root coverage procedure. J Periodontol, 76, 17291734.

Huang LH, Neiva REF, Soehren SE, Giannobile WV, Wang HL, 2005b. The effect of platelet-rich plasma on the coronally advanced flap root coverage procedure: a pilot human trial. J Periodontol, 76, 1768-1777.

Kauvar AS, Thoma DS, Carnes DL, Cochran DL, 2010. In vivo angiogenic activity of enamel matrix derivative. J Periodontol, 81, 1196- 1201. 
Langer B, Langer L, 1985. Subepithelial connective tissue graft technique for root coverage. J Periodontol, 56, 715-720.

Moriyama T, Matsumoto S, Makiishi T, 2009. Root coverage technique with enamel matrix derivative. Bull Tokyo Dent Coll, 50, 97-104.

Rosetti EP, Marcantonio Jr E, Zuzaa EP, Marcantonio RAC, 2013. Root coverage stability of the subepithelial connective tissue graft and guided tissue regeneration: A 30-month follow-up clinical trial. J Dent, 41, 114-120.

Sayar F, Akhundi N, Gholami S, 2013. Connective tissue graft vs. emdogain: A new approach to compare the outcomes. Dent Res J, 10, 38-45.

Sculean A, Windisch P, Keglevich T, Gera I, 2003. Histologic evaluation of intrabony defects following non-surgical periodontal theraphy with and without application of enamel matrix protein derivative. $\mathrm{J}$ Periodontol, 74, 153-160.

Yazışma Adresi:

Doç. Dr. Eylem AYHAN ALKAN

Yüzüncü Yıl Üniversitesi

Diş Hekimliği Fakültesi

Periodontoloji AD

A.D.Zeve Kampüsü, Van, Türkiye

Tel: +90 (505) 7030341

Faks: +90 (432) 2251744

E-mail: eylemayhan79@yahoo.com 